\title{
OB 80-LETNICI PROF. DR. DUŠANA SAVIĆEVIĆA
}

$\mathrm{O}$

80-letnici profesorja Dušana Savićevića so mu njegovi učenci na Katedri za andragogiko na Filozofski fakulteti v Beogradu 2. junija 2006 pripravili znanstveno srečanje na temo Andragogika na začetku tretjega tisočletja. S profesorjem sem opravil intervju, imel pa sem tudi priložnost, da vnovič občudujem njegovo 'očetovsko' skrb za družinico, ki jo je ustvaril na beograjski filozofski fakulteti. Izključno njegova zasluga je, da ima Beograd edini na univerzah nekdanje Jugoslavije samostojno in močno katedro za andragogiko, ki danes šteje 11 redno zaposlenih visokošolskih učiteljev. Nikoli ne bom pozabil dogodka, ko sem bil na obisku pri njem v Beogradu, kako vesel in srečen je bil, ko mu je eden od njegovih študentov prinesel svoje doktorsko delo: kot otrok ga je s ponosom kazal prisotnim in poudarjal, kako pomemben dogodek je to za katedro.

Po letu 1991, ko je praznoval 65-letnico, torej v samo 15 letih je objavil devet obsežnih del: Istraživanja u pedagogiji $i$ andragogiji (Beograd, 1995), Metodologija istraživanja " vaspitanju i obrazovanju (Vranje, 1996),

Dušan (Duško) Savićević še danes, kot je rekel eden od njegovih naslednikov ${ }^{\circ} \mathrm{dr}$. Miomir Despotović, "z njemu lastno skrbjo in posvečenostjo, rekel bi celo trmo«, kljub svojim letom nadaljuje svoje delo za razvoj andragogike kot znanosti in univerzitetne discipline. Na srečanju so udeležencem razdelili njegovo najnovejšo knjigo Andragoške ideje u međunarodnim okvirima in objavili tudi, da je naslednja že v tisku.
Adult Education: From Practice to Theory Building (Frankfurt, 1999), Koreni i razvoj andragoških ideja (Beograd, 2000), Put ka društvu učenja (Beograd, 2000), Filozofski osnovi andragogije (Beograd, 2002), Komparativna andragogija (Beograd, 2003), Učenje $i$ starenje (Beograd, 2005) ter že navedena Andragoške ideje u meäunarodnim okvirima (Beograd, 2006). Seveda je podoben in še obsežnejši seznam knjig, ki jih je izdal pred tem. Če navedem le nekatere: Primena metoda u obrazovanju odraslih (Zagreb, 1961), Problemi integracije u obrazovanju odraslih (Beograd, 1962), Obrazovanje za život u porodici (Beograd, 1967), The System of Adult Education in Yugoslavia (Syracuse, New York, 1968), Povratno obrazovanje (Beograd, 1975), Čovjek i doživotno obrazovanje (Titograd, 1983), Komparativno proučavanje obrazovanja $i$ vaspitanja (Beograd, 1984), Issues and Problems on Comparative Continuing Education of Adults (Madison, 1984), Koncepcija obrazovnih potreba $u$ andra-

Beograjska univerza ima po zaslugi prof. Savićevića samostojno katedro za andragogiko.

gogiji (Beograd, 1989), Savremena shvatanja andragogije (Beograd, 1991), Priroda i karakteristike interesa $u$ andragogiji (Beograd, 1992)

Na koncu svoje uvodne predstavitve dela profesorja Savićevića na posvetu v Beogradu je Miomir Despotović simpatično rekel: »Skrbno nas je izbiral - kolikor se je moglo izbirati in izbrati. Ni nam, tako kot tudi sebi, niti malo prizanašal, česar ne bomo pozabili in mu tudi ne oprostili, posebno še, kadar je vztrajno 
Profesor Savićević je uspešno vodil številne teoretične in razvojne projekte doma in v tujini, aktivno sodeloval pri delu nacionalnih in mednarodnih konferenc in srečanj, bil sodelavec UNESCA, OECD-ja in Sveta Evrope, član uredništev domačih in mednarodnih revij (npr. International Journal of Adult Education, Convergence, International Journal of Lifelong Education, Andragoške studije), bil gostujoči profesor na številnih tujih univerzah, obiskal andragoške ustanove na vseh kontinentih (mednarodno dejavnost podrobno opisuje v svoji zadnji knjigi). Njegova zdajšnja razmišljanja vsebuje intervju, ki smo ga naredili z njim. Uvodoma naj le še navedem gesto, ki je požela splošno odobravanje. Katedri za andragogiko je podaril vso svojo bogato strokovno knjižnico, ki šteje več kot 7000 knjig.

iskal tudi tisto, česar ni mogoče niti dati niti narediti. Toda to, česar ne moremo pozabiti, je njegov človeški in korekten osebni odnos do mlajših sodelavcev, ki jih - začenši že s prvim

Prof. dr. Savićević je po letu 1991, torej $\vee 15$ letih, izdal 9 obsežnih knjig! delovnim dnem - ni obravnaval le kot svoje pomočnike pri učnem in znanstvenem delu, temveč kot polnopravne sodelavce, in spoštovanje, ki jim ga je izkazoval kot akademikom in osebnostim, ki si zaslužijo vso njegovo pozornost in spoštovanje. Za to se mu ne bom zahvaljeval, saj za to, kakršen je nekdo in kako je (samo)oblikovan in narejen, se mu drugi nimamo kaj zahvaljevati!«

Dr. Zoran Jelenc 